\title{
The Crescent Lake copper deposit, central Newfoundland: deep levels of a volcanogenic hydrothermal system?
}

\author{
Craig J. Waldie, E. Craig Jowett \\ Department of Earth Sciences, University of Waterloo, Waterloo, Ontario N2L 3G1, Canada
}

and

H. Scott Swinden
Department of Mines and Energy, P.O. Box 8700, St. John's, Newfoundland A1B 4J6, Canada

Date Received August 24, 1990

Date Accepted December 20, 1990

\begin{abstract}
The Crescent Lake Mine, near the village of Robert's Arm in central Newfoundland, produced small tonnages of high-grade copper ore from quartz veins in the late 1800 's and the 1920 's. Although a Crescent Lake-type deposit is not a viable exploration target in itself, its presence has been used to suggest a potential for either volcanogenic massive sulphides (VMS) such as the nearby Pilley's Island deposit, or for mesothermal or epithermal gold. Field relationships, petrography, geochemistry, mineral chemistry, and fluid inclusion and stable isotopic studies are used to constrain the genesis of the deposit. Mineralization occurs in four sulphide stages and a late oxide stage, distinguished by ore microscopy. Sphalerite, galena, chalcopyrite, and newly recognized carrollite were deposited with quartz between two pyrite stages. Covellite and iron oxides indicate later oxidation. Fluid inclusions in vein quartz are aqueous fluid-vapour type with no daughter crystals, no $\mathrm{CO}_{2}$ or $\mathrm{CH}_{4}$, no boiling, and a narrow range of salinities $\left(\sim 3-7 \% \mathrm{NaCl}_{\text {equiv }}\right)$. The sulphides were likely deposited from homogeneous fluids at $>430 \mathrm{~m}$ depth. The wide range of homogenization temper atures $\left(\sim 112-250^{\circ} \mathrm{C}\right)$ can be interpreted as the result of either changing temper ature or fluctuating fluid pressures during the episodic crack-seal vein formation. Ore-related chlorite has a distinctive blue birefringence and higher $\mathrm{Fe} / \mathrm{Fe}+\mathrm{Mg}$ values $(\sim 0.51$ vs. 0.42$)$ than chlorite in barren host rock, similar to other VMS deposits. The average calculated crystallization temperature of hydrothermal chlorite $\left(240 \pm 2^{\circ} \mathrm{C}\right)$ is close to the maximum fluid inclusion homogenization temperatures and likely closer to the true fluid trapping temperature. Sulphur isotope determinations $\left(\partial^{34} S_{p y} \approx 5.4 ; \partial^{34} S_{c p} \approx 2.8\right.$; $\left.\partial^{34} S_{\mathrm{sp}} \approx 2.2\right)$ are similar to the Gull Pond VMS deposit; they indicate isotopic disequilibrium between coeval sulphides but a homogeneous sulphur source during the ore-forming event. This study concludes that the Crescent Lake copper deposit is most likely part of a volcanogenic hydrothermal stockwork, possibly genetically related to the Pilley's Island deposit.
\end{abstract}

La mine de Crescent Lake, située dans la région centrale de Terre-Neuve à proximité du village de Robert's Arm, produisit de faibles tonnages de minerai à forte teneur en cuivre, issu de veines de quartz, vers la fin des années 1800 et dans les années 1920. Bien qu'un gîte de type Crescent Lake tout seul ne constitue pas une cible d'exploration viable, sa présence a été utilisée pour suggérer l'éventualité soit d'amas sulfurés volcanogènes(ASV), tel que le gîte avoisinant de Pilley's Island, soit d'or mésoou épithermal. La confrontation des données concernant les rapports sur le terrain, la pétrographie, la géochimie, la chimie des minéraux, ainsi que l'étude des inclusions fluides et des isotopes stables, est employée pour définir la genèse du gîte. La minéralisation se présente sous forme de quatre stades à sulfures et d'un stade tardif à oxydes, que l'on reconnaît à l'aide de la microscopie métallographique. La sphalérite, la galène, la chalcopyrite ainsi qu'une carrollite découverte récemment, se sont accumulées avec du quartz entre deux stades à pyrite. De la covellite et des oxydes de fer témoignent d'une oxydation ultérieure. Les inclusions fluides au sein du quartz filonien sont du type à fluide aqueux et vapeur, sans crystaux rejetons, $\mathrm{CO}_{2}, \mathrm{CH}_{4} \mathrm{ni}$ ébullition, et montrent une gamme peu étendue de salinités $(\sim 3-7 \%$ équiv. $\mathrm{NaCl})$. Il semble que les sulfures aient précipité à partir de fluides homogènes à une profondeur dépassant $430 \mathrm{~m}$. Les valeurs très dispersées des températures d'homogénéisation ( 112$250^{\circ} \mathrm{C}$ ) pourraient résulter soit de changements de température, soit de fluctuations dans la pression du fluide, durant la formation épisodique de filons par colmatage de fractures en traction. La chlorite alliée au minerai possède une biréfringence bleue caractéristique et des valeurs plus élevées du rapport $\mathrm{Fe} / \mathrm{Fe}+\mathrm{Mg}(\sim 0.51$ vs. 0.42$)$ que la chlorite présente dans la roche encaissante stérile, ce qui s'apparente aux autres gisements ASV. La moyenne calculée des températures de cristallisation de la chlorite hydrothermale $\left(240 \pm 2^{\circ} \mathrm{C}\right)$ se situe près des températures maximales d'homogénéisation des inclusions fluides et $\mathrm{s}$ 'approche vraisemblablement plus des températures réelles de capture des fluides. Le dosage des isotopes du soufre $\left(\delta^{34} \mathrm{~S}_{p y} \approx 5.4 ; \delta^{34} \mathrm{~S}_{\mathrm{cp}}\right.$ $\left.\approx 2.8 ; \delta^{34} S_{a p} \approx 2.2\right)$ ressemble à celui du gisement $A S V$ de Gull Pond; il témoigne d'un déséquilibre isotopique entre des sulfures synchrones mais aussi d'une source homogène du soufre durant l'épisode métallogène. Une conclusion de cette étude est que 
le gîte cuprifere de Crescent Lake fait le plus vraisemblablement partie d'un stockwerk volcanogène hydrothermal, possiblement relié par sa genèse au gîte de Pilley's Island.

[Traduit par le joumal]

\section{INTRODUCTION}

The Crescent Lake Mine, located near the village of Robert's Arm in the Green Bay, Notre Dame Bay area of central Newfoundland (Fig. 1), is the largest of a number of epigenetic base metal prospects associated with quartz veining and wall-rock alteration in the Robert's Arm-Crescent Lake area. In the late 1800 's, 1100 tonnes of chalcopyrite ore grading $28 \% \mathrm{Cu}$ were mined from this small, rich, quartz vein-hosted copper deposit (Espenshade, 1937). Subsequently, from 1924 to 1926, 1800 tonnes of $12 \% \mathrm{Cu}$ ore were removed. The property has been explored since 1926 by various companies but with discouraging results (MacQuarrie, 1976).

Three inclined shafts follow the dip of the main vein toward Crescent Lake and two vertical shafts intersect the easternmost inclined shaft (Espenshade, 1937). At present the shafts are filled with rubble, and most of the dump material was removed for road and wharf construction in 1974 (Swinden et al., 1988).
Two genetic models have been proposed for the deposit on the basis of field characteristics. Wallrock alteration and sulphide mineralization is similar to that of the nearby Pilley's Island volcanogenic massive sulphide deposit (Fig. 1), suggesting an analogy with a deep-level stockwork formed in a volcanogenic hydrothermal system (Swinden et al., 1988). Alternatively, the sheeted quartz veining suggests a syn-tectonic mesothermal or epithermal vein deposit formed when metals indigenous to the volcanics were tectonically remobilized during later faulting (Bostock, 1978).

Although a Crescent Lake-type deposit is not a viable exploration target in itself, its genesis has direct implications for the exploration industry. On one hand, the deposit may indicate the presence of volcanogenic massive sulphides higher in the stratigraphy; on the other, it may represent the effects of the mesothermal gold event which is now widely recognized in central Newfoundland (Tuach et al., 1988).

This paper presents field relationships, petrography, geochem-

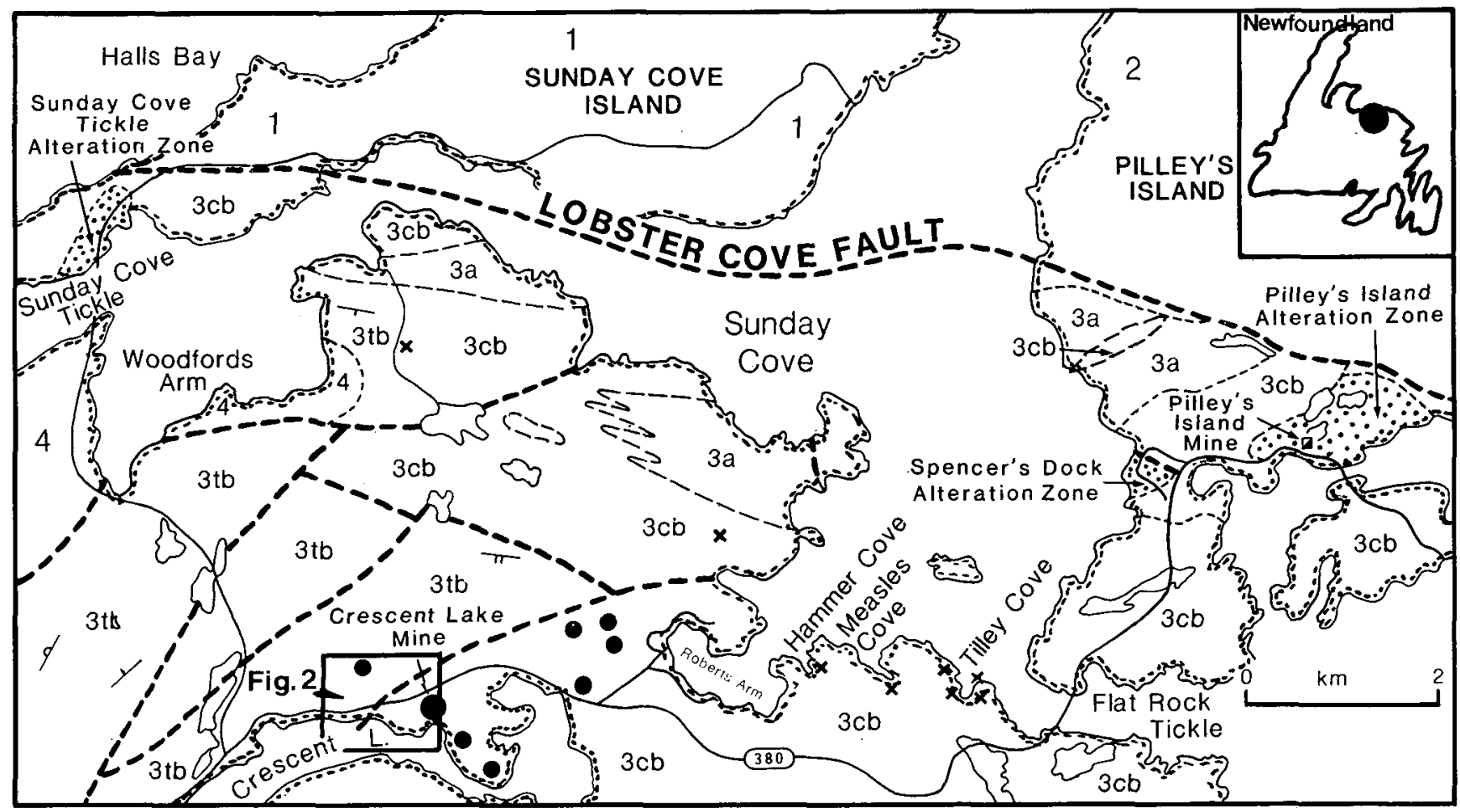

EARLY SILURIAN:

4. Sunday Cove Pluton: granodiorite, quartz-monzonite

3. Robert's Arm Group: 3a - felsic volcanics; 3cb - mafic calc-alkalic volcanics; 3tb - mafic tholeiitic volcanics

2. Cutwell or Western Arm Group equivalent?. mafic, intermediate volcaniclastics, pyroclastics

1. Lushs Bight Group: mafic pillow lava, sheeted dikes

Fig. 1. Location (shown on inset map of Newfoundland) and generalized geology (after Bostock, 1978) of the Crescent Lake and Pilley's Island area. Alteration zones in stipple are after Tuach (1984). Mineral occurrences of Crescent Lake-type shown by solid dots; faults shown by heavy dashed lines (after Swinden, 1987). 
istry, mineral chemistry, fluid inclusion studies, and stable isotopic studies carried out to constrain the genesis of the deposit, and provides evidence that it might well represent the deep levels of a volcanogenic hydrothermal system.

\section{GEOLOGIC SETTING}

\section{Regional geology}

The Crescent Lake Mine is hosted by Lower Ordovician volcanic rocks of the Robert's Arm Group (Fig. 1). Regionally, this group forms part of an extensive belt of dominantly calcalkalic, mafic, and lesser felsic volcanic rocks termed the "Buchans-Robert's Arm Belt" (Strong, 1977; Dean, 1978). This volcanic belt is generally considered to be an island arc in the Ordovician "Iapetus" ocean (Strong, 1977; Thurlow et al., 1975; Bostock, 1988). The Buchans-Robert's Arm belt is a prolific host of volcanogenic massive sulphide deposits, with major former producers at Buchans, Gullbridge, and Pilley's Island, and scores of lesser prospects and showings (Kean et al., 1981; Swinden and Sacks, 1986; Bostock, 1988).

The Crescent Lake Mine is the largest of several small base metal prospects associated with quartz veining and wall rock alteration in the area between Robert's Arm and Crescent Lake (Fig. 1). The Robert's Arm Group in the area comprises a dominantly north-facing sequence of mafic pillow lavas, which has been disrupted by a number of prominent strike-slip faults (Bostock, 1988) (Fig. 2). The deposit occurs just north of a terrane-bounding major fault ("Crescent Lake-Sops Arm Fault" of Bostock, 1988), near the structural and stratigraphic base of a thick $(>3 \mathrm{~km}$ ) sequence of basalts interpreted as calc-alkalic on the basis of major element geochemistry (Bostock, 1988).

The volcanism north of Crescent Lake becomes more silicic up-section, and the exposed top of the succession, in the Sunday Cove and Pilley's Island areas, is characterized by considerable volumes of dacite and rhyolite (Fig. 1). On Pilley's Island, a dacite dome interbedded with calc-alkalic pillow basalts hosts, and is genetically related to the Pilley's Island volcanogenic massive sulphide deposit (Tuach, 1984). Similar volcanic alteration occurs at approximately the same stratigraphic horizon on Sunday Cove Island (Sunday Cove Tickle alteration zone; Fig. 1). Stratigraphic reconstruction indicates that the Pilley's Island deposit may be as much as $2000 \mathrm{~m}$ stratigraphically above the Crescent Lake Mine, although movement along the intervening faults is poorly constrained.

\section{Geochemistry of Robert's Arm volcanics}

In an effort to confirm the calc-alkalic nature of the volcanic pile and to test whether volcanic rocks in the Crescent Lake area can be considered part of a continuous volcanic sequence, including the volcanogenic massive sulphides at Pilley's Island, several samples from Bostock (1988) from the two areas were analyzed for additional trace elements including rare earth elements (REE) (Fig. 3a, b). Major elements and the trace elements $\mathrm{Cr}, \mathrm{Ni}$, and V were previously determined by X-ray fluorescence. Representative analyses are given in Table 1 . All other reported trace elements were determined by inductively coupled plasma-mass

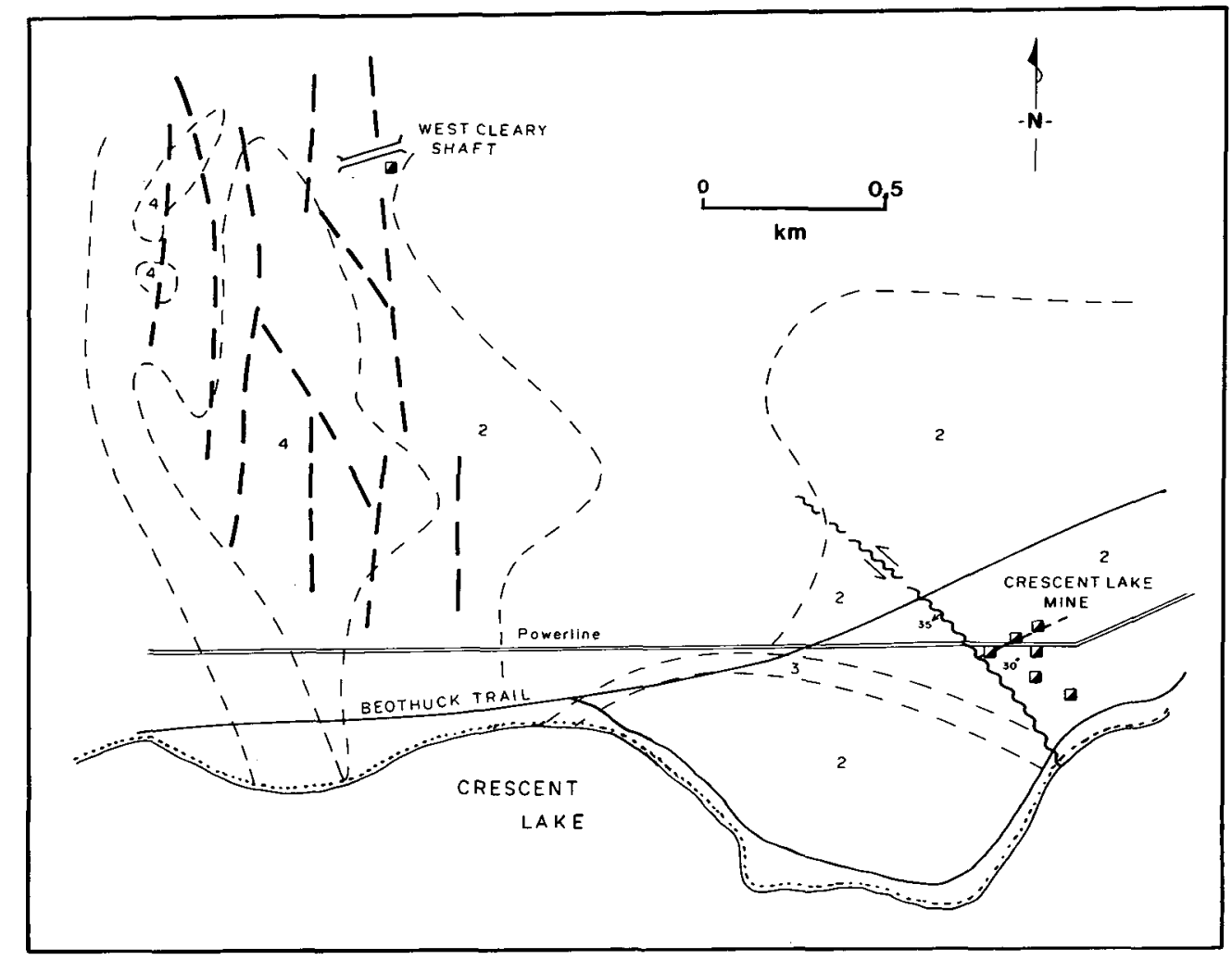

Fig. 2. Geology of the Crescent Lake Mine area. The heavy dashed lines represent the mineralized vein system. 1 - hematitized pillow lava, pillow basalt; 2 - non-hematitized pillow lava; 3 - red argillite, siltstone, chert; 4 - West Cleary pluton, subvolcanic gabbro, granodionite. Location of old shafts indicated by half-closed squares (after MacQuarrie, 1976; Swinden et al., 1988). 
A

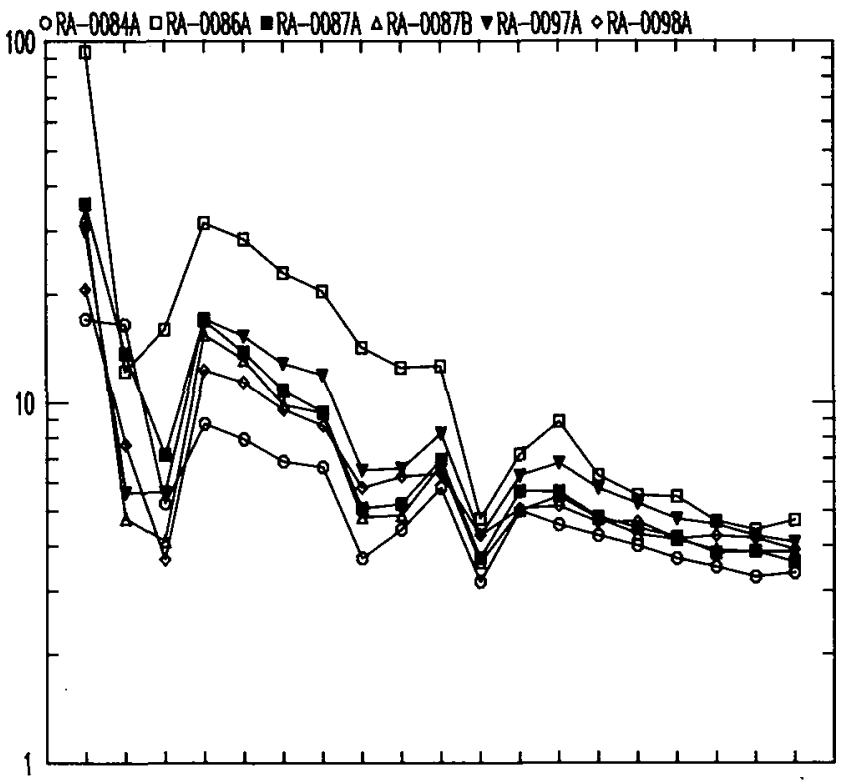

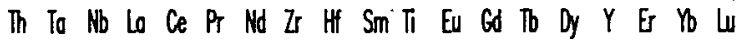

B

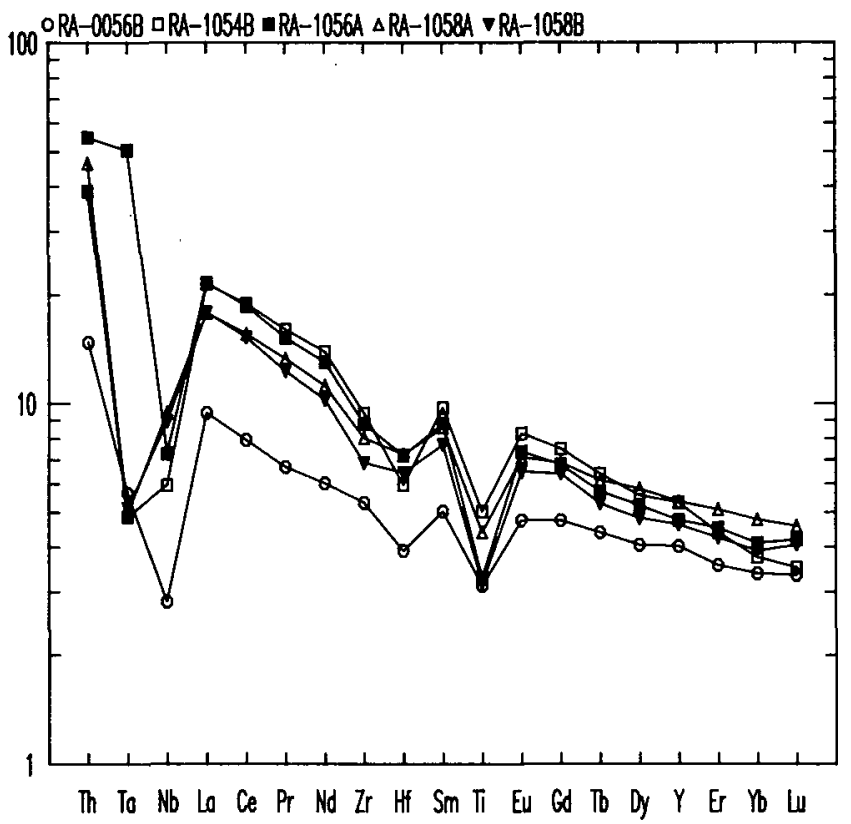

Fig. 3. Rare earth and trace element plots (chondrite-normalized) for Robert's Arm volcanic rocks in (A)Crescent Lake area, and (B) Pilley's Island area, indicating calc-alkalic affinity and similarity between the two regions.

spectrometry at Memorial University of Newfoundland. Analytical methods and estimates of accuracy and precision are in Bostock (1988) and Jenner et al. (1990).

The data show that $\mathrm{TiO}_{2}$ in mafic volcanic rocks north of Crescent Lake and in the Pilley's Island area does not increase with fractionation, a feature characteristic of calc-alkalic magma series (Miyashiro and Shido, 1975). The extended REE patterns in Figure $3 a$ and $b$ show that these rocks are moderately enriched in the light REE, also typical of calc-alkalic volcanics, and have
Table 1. Mafic volcanic whole rock analyses from the Crescent Lake (RA-87) and Pilley's Island (RA-1058) Mines. Recalculated to $100 \%$ anhydrous.

\section{RA-87A RA-87B RA-1058A RA-1058B}

\begin{tabular}{|c|c|c|c|c|}
\hline $\mathrm{SiO}_{2} \%$ & 52.71 & 54.00 & 51.53 & 46.70 \\
\hline $\mathrm{TiO}_{2}$ & 0.70 & 0.68 & 0.83 & 0.60 \\
\hline $\mathrm{Al}_{2} \mathrm{O}_{3}$ & 15.43 & 14.65 & 16.51 & 15.23 \\
\hline $\mathrm{FeO}$ & 8.77 & 7.64 & 8.00 & 5.42 \\
\hline $\mathrm{MnO}$ & 0.17 & 0.16 & 0.11 & 0.17 \\
\hline $\mathrm{MgO}$ & 8.39 & 7.54 & 7.09 & 5.48 \\
\hline $\mathrm{CaO}$ & 9.11 & 9.63 & 10.57 & 23.64 \\
\hline $\mathrm{Na}_{2} \mathrm{O}$ & 4.56 & 5.44 & 2.86 & 1.70 \\
\hline $\mathrm{K}_{2} \mathrm{O}$ & 0.01 & 0.10 & 2.27 & 0.85 \\
\hline $\mathrm{P}_{2} \mathrm{O}_{5}$ & 0.14 & 0.16 & 0.23 & 0.20 \\
\hline Cr ppm & 367 & 395 & 242 & 186 \\
\hline $\mathrm{Ni}$ & 136 & 144 & 68 & 44 \\
\hline V & 267 & 271 & 204 & 148 \\
\hline $\mathrm{Cu}$ & 92 & 92 & 2 & 11 \\
\hline $\mathrm{Pb}$ & 0 & 0 & 6 & 3 \\
\hline $\mathrm{Zn}$ & 58 & 61 & 54 & 43 \\
\hline $\mathbf{R b}$ & 1 & 1 & 57 & 17 \\
\hline $\mathrm{Ba}$ & 96 & 115 & 301 & 147 \\
\hline $\mathrm{Sr}$ & 203 & 200 & 158 & 145 \\
\hline $\mathrm{Ta}$ & 0.55 & 0.19 & 0.2 & 0.21 \\
\hline $\mathrm{Nb}$ & 4.6 & 2.7 & 6.1 & 5.8 \\
\hline Hf & 1.46 & 1.36 & 2.02 & 1.8 \\
\hline $\mathrm{Zr}$ & 50 & 47 & 79 & 67 \\
\hline $\mathrm{Y}$ & 16 & 16 & 21 & 18 \\
\hline Th & 3.14 & 2.9 & 4.08 & 3.37 \\
\hline $\mathrm{La}$ & 10.65 & 9.74 & 11.24 & 11.26 \\
\hline $\mathrm{Ce}$ & 21.84 & 20.81 & 24.68 & 24.18 \\
\hline Pr & 2.71 & 2.47 & 3.34 & 3.09 \\
\hline Nd & 11.42 & 11.33 & 13.56 & 12.39 \\
\hline $\mathrm{Sm}$ & 2.77 & 2.67 & 3.42 & 3.08 \\
\hline $\mathrm{Eu}$ & 0.85 & 0.75 & 1.06 & 0.97 \\
\hline Gd & 3.01 & 2.93 & 3.65 & 3.4 \\
\hline $\mathrm{Tb}$ & 0.47 & 0.46 & 0.6 & 0.51 \\
\hline Dy & 2.96 & 2.84 & 3.83 & 3.17 \\
\hline $\mathrm{Er}$ & 1.65 & 1.68 & 2.19 & 1.83 \\
\hline $\mathrm{Yb}$ & 1.71 & 1.7 & 2.11 & 1.72 \\
\hline $\mathrm{Lu}$ & 0.24 & 0.25 & 0.3 & 0.27 \\
\hline
\end{tabular}

distinctive positive $\mathrm{Th}$ and negative $\mathrm{Nb}$ anomalies on a chondrite-normalized basis, indicating that they were erupted in an island arc environment (e.g., Sun, 1980). Most have slight negative $\mathrm{TiO}_{2}$ anomalies, perhaps indicating crystallization of an iron-bearing phase such as iron oxides or amphiboles, again consistent with a calc-alkalic fractionation series.

These data suggest that the Crescent Lake and Pilley's Island volcanic rocks are very similar geochemically and that Crescent Lake Mine occupies the structural base of a more or less continuous calc-alkaline sequence which culminates with widespread felsic volcanism and local volcanogenic sulphide deposition in the Pilley's Island area. 


\section{Deposit geology}

According to Espenshade (1937), the composite quartz vein system at the Crescent Lake Mine was exposed in outcrop for about $60 \mathrm{~m}$ over a width of $1.0-4.5 \mathrm{~m}$ (Fig. 2). The mineralized veins are fissure-type within spilitized calc-alkalic basaltic flows and breccias (Bostock, 1988). Sulphide minerals in the quartz include chalcopyrite and pyrite, with minor sphalerite, galena, and covellite. Additional small quartz veins of similar mineralogy occur near the main vein. Espenshade (1937) reported a 76$\mathrm{cm}$ thick mass of chalcopyrite along the footwall of the main vein. Silver values of $10-20 \mathrm{~g} /$ tonne have been reported from the mine dumps (Howse and McArthur, 1977).

Analyses of representative grab samples from the mine area (Table 2) show that $\mathrm{Cu}$ is elevated in almost all samples, while $\mathrm{Zn}$ and $\mathrm{Pb}$ are sporadic. Gold and its tracers $\mathrm{As}$ and $\mathrm{Sb}$ tend to follow $\mathrm{Cu}$. The highest grade sample, \#228E, with $5.6 \% \mathrm{Cu}$, contains anomalous $\mathrm{Au}, \mathrm{Ag}, \mathrm{As}$, and $\mathrm{Sb}$, though not of economic grade.

The mineralized quartz veins are commonly sheeted, suggesting repeated opening and filling of the veins (crack-seal mechanism; Ramsay, 1980) and are locally brecciated and contain inclusions of chloritized wallrock. Base metal sulphides are restricted to the quartz vein material and locally comprise up to $15 \%$ by volume, although average considerably less (Swinden, 1987). Widespread wallrock alteration associated with the veins consists of pervasively chloritized, silicified, and pyritized basalt with local quartz-sericite alteration. Chlorite within the mineralized veins has a distinctive dark green to black colour (Swinden, 1987), similar to VMS stockworks such as the Ansil Mine in Quebec (G. Riverin, personal communication, 1990).

\section{MINERALOGY, TEXTURES, AND PARAGENESIS}

The veins contain quartz, pyrite, chalcopyrite, sphalerite, galena, iron oxide, covellite, and newly recognized carrollite. The sulphides and oxides occur in five discernible paragenetic stages (Fig. 4), established on the basis of textural relationships of ore and gangue minerals observed during this study: pre-ore sulphide stage 1; ore sulphide stages 2 and 3; post-ore sulphide stage 4; and a later oxidized stage 5 .

Quartz appears to occur in the first four stages although it is not possible to identify a distinctive quartz for each distinctive paragenetic stage. However, the quartz veins display sheeting, interpreted to be a crack-seal texture caused by episodic pressure fluctuation and injection of fluids (Ramsay, 1980; Sibson, 1981), forming multiple generations of quartz.

Pyrite is found in silicified and chloritized wallrock and within the quartz veins where it generally forms $1-7 \mathrm{~mm}$ subhedral crystals which are fragmented or "crackled"(Fig. 5a). This pyrite appears to precede formation of base-metal sulphides and is classified as stage 1 . The crystal fragments show little movement or rotation to indicate severe tectonism, and the crackling may be the result of the multiple crack-seal cycles. Pyrite also occurs as unbrecciated subhedral grains $(0.5-3 \mathrm{~mm})$, anhedral masses, and rare euhedral cubic crystals $(0.1 \mathrm{~mm})$. Stage 1 pyrite may contain cross-cutting veinlets of chalcopyrite (Fig. 5e) and occur as brecciated fragments surrounded by stage 2 sphalerite (Fig. $5 b$ ). There is no petrographic evidence to suggest that pyrite is coeval with sphalerite or chalcopyrite even though sulphur isotope values suggest that stage 1 pyrite could have formed in isotopic equilibrium with stage 3 chalcopyrite (discussed later). A second generation of pyrite mantles chalcopyrite and replaces chalcopyrite and sphalerite along fractures and is classified as post-ore, stage 4 pyrite (Fig. $5 f$ ).

Along with galena, sphalerite appears to be the first base-metal sulphide formed and is classified as stage 2. It can occur as small (0.1-3 mm), isolated, and irregular aggregates but more commonly it is intimately associated with chalcopyrite. It is almost always partially replaced by chalcopyrite to form the texture characteristic of "chalcopyrite disease" (Fig. 5d). The diseased sphalerite contains 1-20 $\mu \mathrm{m}$ wide veinlets and round inclusions of replacement chalcopyrite formed when copper-rich fluids reacted with pre-existing sphalerite (Barton, 1978).

Galena occurs in stage 2 as anhedral blebs and irregularly shaped patches in contact with diseased sphalerite and chalcopyrite. Intergrown contacts between galena and diseased sphalerite suggest that they are coeval. Galena infills fractures in quartz and is attached to a pyrite grain which is mantled by iron-oxide (Fig. 5c).

Chalcopyrite occurs dominantly as small $(1-8 \mathrm{~mm})$, isolated anhedral patches, but also cross-cuts and infills fractures in stage 1 pyrite (Fig. 5e). Chalcopyrite was also observed to have replaced stage 2 sphalerite as fine inclusions and veinlets (Fig. 5d) and is thus classified as stage 3. Barton and Bethke (1987)

Table 2. Geochemical analyses of mineralized grab samples from the Crescent Lake Mine.

\begin{tabular}{lrrrrrrr}
\hline Spl. No. & $228 \mathrm{~A}$ & $228 \mathrm{~B}$ & $228 \mathrm{C}$ & $228 \mathrm{D}$ & $228 \mathrm{E}$ & $228 \mathrm{~F}$ & $228 \mathrm{G}$ \\
$\mathrm{Cu} \%$ & 2200 & 1400 & 1100 & 2900 & 56000 & 8900 & 180 \\
$\mathrm{~Pb}$ & 40 & 8 & 12 & 16 & 120 & 22 & 28 \\
$\mathrm{Zn}$ & 110 & 79 & 180 & 4800 & 670 & 170 & 210 \\
$\mathrm{Au} \mathrm{ppb}$ & 2 & 3 & $<1$ & 1 & 74 & 7 & 3 \\
$\mathrm{Ag} \mathrm{ppm}$ & 0.5 & $<.5$ & $<.5$ & 0.5 & 50 & 4 & $<.5$ \\
$\mathrm{As}$ & 130 & 74 & 36 & 110 & 570 & 200 & 60 \\
$\mathrm{Sb}$ & 0.7 & 0.5 & $<.1$ & 1.1 & 8.2 & 0.5 & 0.3 \\
$\mathrm{Ni}$ & 170 & 130 & 270 & 65 & 230 & 7 & 600 \\
\hline
\end{tabular}




\begin{tabular}{|llllll|}
\hline Stage & 1 & 2 & 3 & 4 & 5 \\
\hline & & & & & \\
pyrite & $\mathrm{X}$ & & & $\mathrm{X}$ & \\
sphalerite & $\mathrm{X}$ & & & & \\
galena & & $\mathrm{X}$ & & & \\
chalcopyrite & & & $\mathrm{X}$ & & \\
carrollite & & & $\mathrm{X}$ & & $\mathrm{X}$ \\
covellite & & & & & $\mathrm{X}$ \\
iron oxides & & & & & \\
\hline
\end{tabular}

Fig. 4. Mineral paragenesis at the Crescent Lake deposit inferred from petrographic relationships. Separate pyrite-forming sulphide stages (1 and 4) occur prior and subsequent to the copper-lead-zinc sulphideforming event (stages 2 and 3). A post-sulphide stage (5) in which iron oxides (and covellite) formed indicates a later oxidizing, likely weathering, event.

concluded that chalcopyrite disease occurs in moderate temperature $\left(200-400^{\circ} \mathrm{C}\right)$ deposits that are formed and "quenched" rapidly. Stage 2 sphalerite and galena and stage 3 chalcopyrite may therefore be close in time or even partly coeval. Small amounts of $\mathrm{Au}, \mathrm{Ag}, \mathrm{As}$, and $\mathrm{Sb}$, which correlate with copper content (Table 2), were likely introduced in stage 3 fluids.

Iron oxide mantles earlier pyrite (Fig. 5c), chalcopyrite, and diseased sphalerite, and occurs as fracture fillings in quartz. The timing of the iron-oxide replacement is unclear but its presence indicates that a period of oxidation followed sulphide formation. A notable feature of this oxide is its spongy, cellular texture which is seen in all but the narrowest of veinlets. Colloform growth-banding can be seen in several open fractures where the iron oxide grew by precipitation inwards from the walls of fractures.

Covellite (CuS) replaced diseased sphalerite preferentially, leaving the chalcopyrite inclusions as islands within covellite. Replacement occurred along fractures (Fig. 5d) and at grain boundaries with total replacement seen only in the smallest $(0.1$ $0.5 \mathrm{~mm}$ ) sphalerite grains. Timing of the covellite replacement is unclear but it possibly formed during the same oxidizing conditions as the iron oxide (stage 5).

An unknown, yellow-white mineral was identified as carrollite $\left[(\mathrm{Cu}, \mathrm{Ni}) \mathrm{Co}_{2} \mathrm{~S}_{4}\right]$ of composition $10.8 \% \mathrm{Cu}, 10.8 \% \mathrm{Ni}, 38.9 \% \mathrm{Co}$, $0.6 \% \mathrm{Fe}$, and $41.6 \% \mathrm{~S}$ by microprobe analysis at the University of Toronto. It occurs as small $(20 \mu \mathrm{m})$ separate grains or compact masses enclosed within chalcopyrite, similar to textures described by Ramdohr (1969) for carrollite in hydrothermal vein systems. About ten individual grains of carrollite were observed in only one sample collected from the mine dump.

\section{FLUID INCLUSION STUDY}

\section{Sample selection}

In order to obtain temperatures of ore formation, vein quartz intimately associated with base-metal sulphides was used for fluid inclusion analysis. Clear quartz was selected where possible because it is generally less fractured and contains fewer secon- dary fluid inclusions than cloudy quartz. Severely fractured samples were rejected. Twenty slabbed surfaces were examined to obtain several ages of quartz, but no cross-cutting relationships were observed. The clearest material and the quartz that yielded the most useable inclusions was found immediately adjacent to ore sulphides, and thus is more likely coeval. Therefore, even though the relative age of quartz could not be discerned, ore-stage quartz was probably sampled preferentially.

\section{Description and classification}

Quartz veins from Crescent Lake contain visible fluid inclusions of $1-5 \mu \mathrm{m}$ size with the majority $<3 \mu \mathrm{m}$. This small size made the critical phase changes during freezing and heating difficult to observe and limited the number of measurements obtainable. The error in measurement is thus limited by the accuracy of the observer rather than the instrumentation.

Only halite-undersaturated, aqueous liquid-vapour type inclusions were observed in this study. They homogenize by expansion of the liquid and disappearance of the vapour phase upon heating (Fig. 5g). No daughter minerals and no other gases or liquids such as $\mathrm{CO}_{2}$ were observed. The range in volume percentage of the vapour phase in the inclusions was visually estimated at 3-8 vol. \% (Roedder, 1984). No wide variation in vapour/liquid ratios in coeval inclusions, which otherwise would indicate boiling, was observed.

The inclusions are also classified chronologically as primary, secondary, or pseudo-secondary (Roedder, 1984). The repeated fracturing of the quartz noted earlier is evident from the abundant planes of fluid inclusions along healed fractures. These pseudosecondary inclusions represent fluids present during subsequent crack-seal cycles, and are therefore possibly ore-stage. However, they cannot be distinguished from secondary inclusions along later healed fractures. Primary inclusions occur in planes along crystal growth zones, but in this study, these are too small $(<1$ $\mu \mathrm{m})$ to be used. Single, isolated inclusions in this study are also considered primary. Inclusions showing evidence of necking or leakage (Roedder, 1984) were rejected.

\section{Equipment and methodology}

Temperatures of phase changes in fluid inclusions were measured with a chromel-constantan thermocouple attached to a Doric 410A digital trendicator with a Fluid Inc. gas-flow heating/ freezing system. The equipment was calibrated using synthetic fluid inclusion standards (pure $\mathrm{H}_{2} \mathrm{O}$ and pure $\mathrm{H}_{2} \mathrm{O}+\mathrm{CO}_{2}$ ) provided by Fluid Inc. Temperature variations within the heating stage are $<0.1^{\circ} \mathrm{C}$ at $-56.6^{\circ} \mathrm{C}$ and $0.0^{\circ} \mathrm{C}$, and less than $1^{\circ} \mathrm{C}$ at $290^{\circ} \mathrm{C}$.

Doubly polished sections (80-100 $\mu \mathrm{m}$ thick) were examined prior to measurement, and the type, size, shape, distribution, vapour phase volume, and relationship of inclusions with respect to sulphides recorded. Inclusions suitable for further study were noted and 3-7 $\mathrm{mm}$ size chips removed from the polished plate for measurement. Each inclusion was subjected to several freezing and heating runs to minimize errors. An average temperature was recorded for each inclusion. 


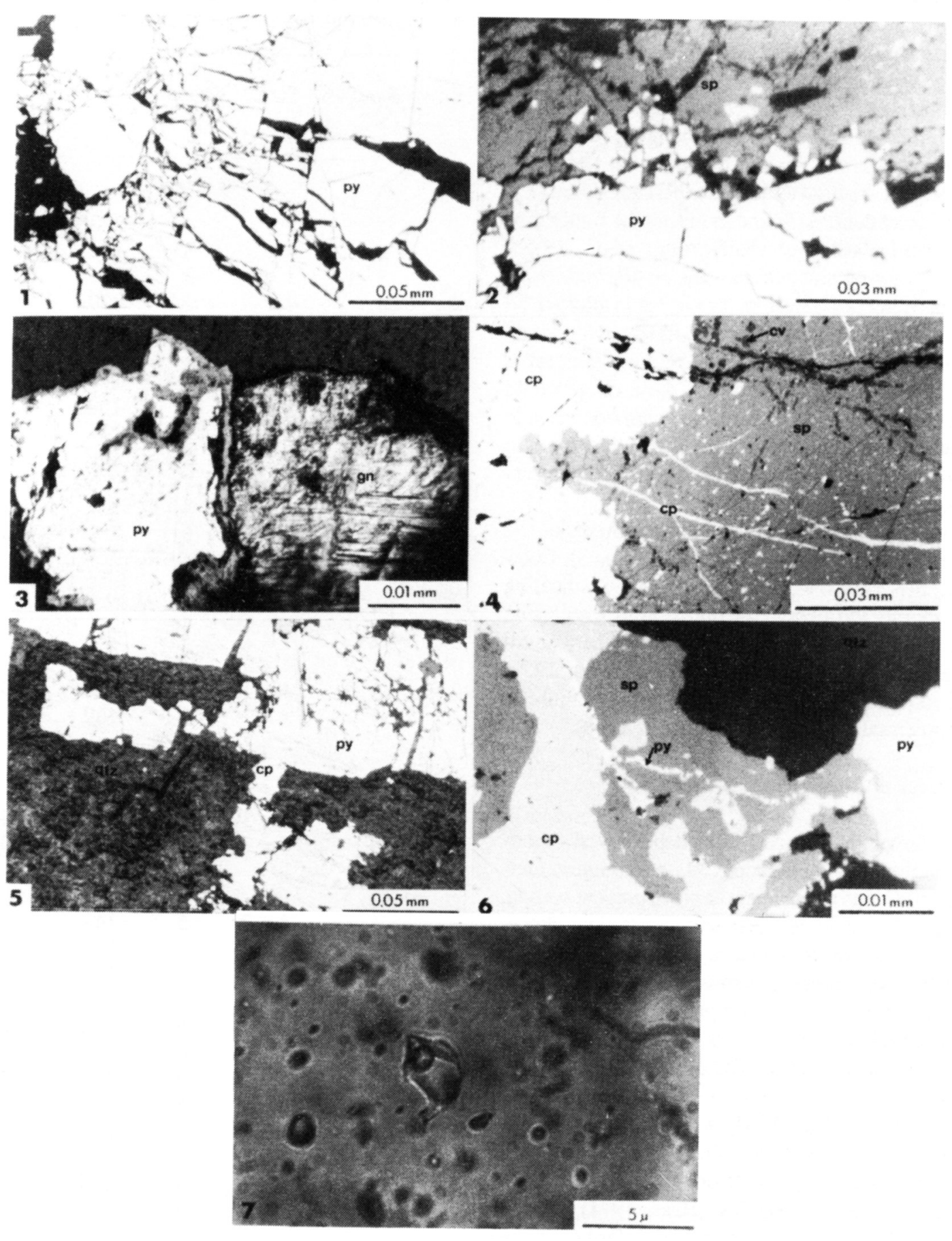

Fig. 5. (1) Earliest sulphide (stage 1) is crackled pyrite (py). $\partial^{34} \mathrm{~S}_{p y}=5.0-6.2 \%$. (2) Brecciated fragments of stage 1 pyrite (py) incorporated into later stage 2 sphalerite (sp). $\partial^{34} \mathrm{~S}_{\mathrm{ap}}=2.3 \%$. (3) Mantling of pyrite (py) grain by stage 5 iron oxide adjacent to a grain of stage 2 galena (gn). (4) Randomly orientated blebs and veinlets of chalcopyrite (cp) in stage 2 sphalerite (sp) (chalcopyrite disease). Covellite (cv) (stage 5?) replaces sphalerite (sp) along fractures. Note also the concave grain boundaries between chalcopyrite and sphalerite. $\partial^{34} \mathrm{~S}_{c \mathrm{p}}=2.2-3.4 \%$. $(5)$ Fractured stage 1 pyrite (py) cut by a later vein of stage 3 chalcopyrite (cp). Consistent isotope fractionation between stage 1 pyrite and stage 3 chalcopyrite suggests equilibrium, but because the sulphides are not coeval, a more likely explanation is that sulphur source was fairly constant with time. (6) Chalcopyrite diseased stage 2 sphalerite (sp) and stage 3 chalcopyrite (cp) cut by a later, post-ore stage 4 pyrite (py) introduced along a fracture. (7) Primary fluid inclusion in quartz containing aqueous liquid and vapour. Homogenization temperatures range widely between $112^{\circ}$ and $250^{\circ} \mathrm{C}$. Salinities range narrowly between 3.3 and $6.6 \mathrm{wt}$. \% $\mathrm{NaCl}$ equivalent. 


\section{Microthermometry results}

During heating, the separate liquid and vapour phases become one at the homogenization temperature $\left(T_{n}\right)$; in this study the diminishing vapour bubble disappeared into the liquid phase. The $T_{b}$ were uncorrected for pressure and therefore provide an estimate of the minimum temperature of formation (Roedder, 1984). During freezing, the final melting temperature of ice $\left(T_{m}\right)$ gives the freezing-point depression and therefore the fluid salinity as weight percent $\mathrm{NaCl}$ equivalent (Potter et al., 1978). Detailed results of freezing and heating runs on 40 fluid inclusions from quartz veins are given in Table 3 and plotted on histograms (Figs. 6, 7). Homogenization temperatures for quartz (Fig. 6) range widely between 112 and $250^{\circ} \mathrm{C}$ with noticeable clusters at $130-140^{\circ}$ and $200-220^{\circ} \mathrm{C}$. This wide range could reflect a protracted quartz- and ore-forming event over a wide temperature range at constant pressure, or alternatively, could result from a wide range of fluid pressures at constant temperature (see below).

Measurements of $T_{m}$ were hindered by the small size of the inclusions, and not all samples have $\mathrm{T}_{\mathrm{m}}$ values (Table 3). Compositions range from 3.3 to $6.6 \mathrm{wt}$. \% NaCl equivalent, indicating a fairly constant salinity throughout the ore-forming event (Fig. 7). These temperatures and salinities are similar to the Kuroko stockwork and related $\mathrm{Cu}-\mathrm{Pb}-\mathrm{Zn}$ veins (Hattori and Sakai, 1979; Pisutha-Arnond and Ohmoto, 1983), but higher than the 0-3\% salinities of mesothermal gold deposits (Roberts, 1988).

\section{Genetic significance of fluid inclusion data}

The fluids that formed the Crescent Lake deposit were homogeneous, slightly saline brines, without $\mathrm{CO}_{2}$, at minimum temperatures of $112-250^{\circ} \mathrm{C}$, and at sufficient depth to prevent boiling. The field evidence of successive crack-seal cycles (Swinden $e t$ al., 1988) does not resolve the constant pressure or constant temperature question, but rather is permissive with either. The crack-seal evidence indicates that fluid pressures certainly did fluctuate; from near-lithostatic just prior to cracking to nearhydrostatic when the crack opened. The absence of coexisting vapour-dominant inclusions in the vein system suggests that boiling did not occur (Roedder, 1984) when pressure was released. For a fluid at $250^{\circ} \mathrm{C}$ with a salinity of $5 \mathrm{wt} \% \mathrm{NaCl}$ equivalent, a fluid pressure of $3.9 \mathrm{MPa}$ or a minimum depth of $428 \mathrm{~m}$ is necessary to prevent boiling (Haas, 1971). Quartz formed at higher fluid pressures would yield $a T_{b}$ far below the real trapping temperature.

\section{MINERAL CHEMISTRY}

\section{Analytical method}

All mineral compositions were determined from polished sections by energy dispersive electron microprobe analysis at the University of Toronto. An Etec Autoprobe equipped with a Lidrifted Kevex Si detector and "on-line" data reduction using a "peak stripping" program was used (C. Cermignani, personal communication, 1989). Accelerating voltage was $20 \mathrm{kV}$ with a
Table 3. Primary fluid inclusion data from Crescent Lake quartz veins.

\begin{tabular}{cccccc} 
Sample & $\begin{array}{l}\text { Size } \\
\mu \mathrm{m}\end{array}$ & $\begin{array}{c}\text { Vapour } \\
\%\end{array}$ & $\begin{array}{c}\mathrm{T}_{\mathrm{h}} \\
{ }^{\circ} \mathrm{C}\end{array}$ & $\begin{array}{c}\mathrm{T}_{\mathrm{m}} \\
{ }^{\circ} \mathrm{C}\end{array}$ & $\begin{array}{c}\text { Salinity } \\
\% \mathrm{NaCl}\end{array}$ \\
\hline $\mathrm{CL} 1$ & & & & & \\
1 & $5 \times 2$ & 4 & 228 & -3.2 & 5.2 \\
2 & $4 \times 2$ & 3 & 182 & & \\
3 & $4 \times 3$ & 3 & 140 & -3.5 & 5.7 \\
4 & $4 \times 4$ & 5 & 220 & -2.0 & 3.3 \\
5 & $3 \times 2$ & 4 & 136 & & \\
6 & $3 \times 1$ & 4 & 220 & & \\
7 & $3 \times 3$ & 3 & 190 & & \\
8 & $5 \times 3$ & 5 & 160 & -4.1 & 6.6 \\
9 & $2 \times 3$ & 5 & 187 & & \\
10 & $3 \times 3$ & 5 & 130 & & \\
11 & $5 \times 4$ & 8 & 250 & -3.4 & 5.5 \\
12 & $4 \times 4$ & 4 & 202 & -2.6 & 4.3 \\
13 & $4 \times 4$ & 5 & 200 & -3.6 & 5.8 \\
14 & $5 \times 5$ & 4 & 208 & -2.8 & 4.6
\end{tabular}

$\begin{array}{clllll}\text { CL } 2 & & & & & \\ 1 & 4 \times 2 & 3 & 211 & & \\ 2 & 4 \times 3 & 5 & 142 & -3.0 & 4.9 \\ 3 & 4 \times 4 & 4 & 200 & -4.0 & 6.4 \\ 4 & 2 \times 2 & 6 & 189 & & \\ 5 & 2 \times 2 & 4 & 195 & & \\ 6 & 3 \times 2 & 3 & 179 & & \\ 7 & 2 \times 2 & 3 & 218 & & \\ 8 & 4 \times 3 & 5 & 150 & -2.4 & 4.0 \\ 9 & 4 \times 3 & 4 & 212 & -3.3 & 5.4 \\ & & & & & \\ \text { CL } 4 & & & & & \\ 1 & 4 \times 2 & 5 & 141 & & \\ 2 & 4 \times 3 & 4 & 134 & -2.1 & 3.5 \\ 3 & 3 \times 3 & 5 & 113 & & \\ 4 & 4 \times 3 & 5 & 202 & -3.5 & 5.7 \\ 5 & 4 \times 3 & 5 & 125 & -4.0 & 6.4 \\ 6 & 2 \times 2 & 4 & 132 & & \\ 7 & 4 \times 3 & 4 & 112 & -4.1 & 6.6 \\ 8 & 3 \times 2 & 5 & 190 & & \\ 9 & 3 \times 3 & 6 & 215 & & \\ 10 & 5 \times 3 & 5 & 203 & -2.9 & 4.8 \\ 11 & 4 \times 3 & 4 & 208 & -4.0 & 6.4 \\ 12 & 3 \times 2 & 3 & 230 & & \\ \text { CL } 5 & & & & & \\ 1 & 4 \times 2 & 3 & 189 & & \\ 2 & 2 \times 2 & 4 & 124 & & \\ 3 & 4 \times 3 & 4 & 211 & -3.2 & 5.2 \\ 4 & 3 \times 3 & 4 & 207 & -3.6 & 5.8 \\ 5 & 3 \times 2 & 5 & 218 & -4.0 & 6.4 \\ & & & & & \end{array}$

beam current of $0.120 \mathrm{nA}$. Intensity calibration was performed on Co metal with 100 second (live time) for all analyses. Two mineral grains were analyzed from each sample with good reproducibility. Standards approximating each uncalibrated mineral analysis were used as follows: natural chlorite for $\mathrm{Si}, \mathrm{Al}$, 


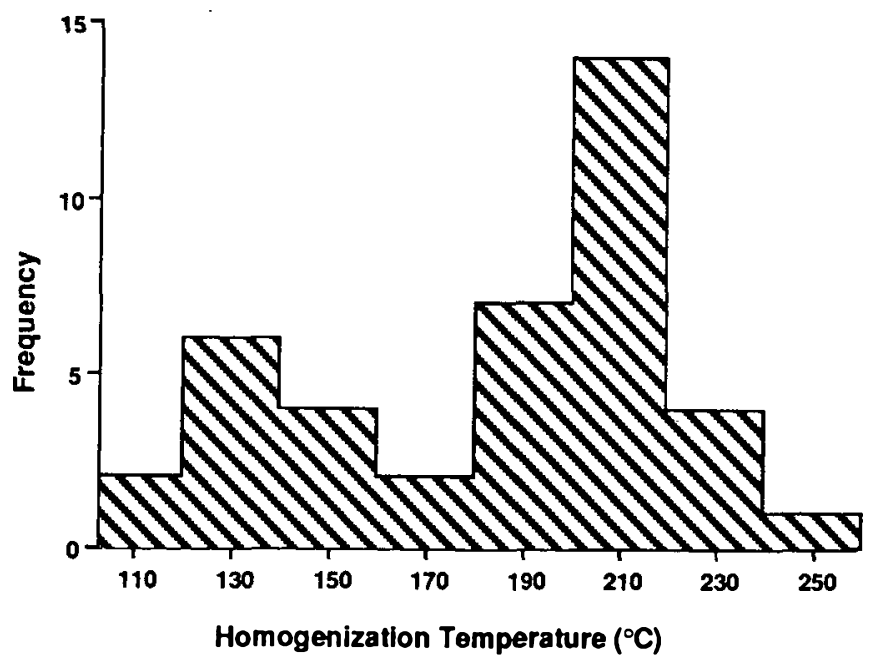

Fig. 6. The wide range of homogenization temperatures of primary fluid inclusions from Crescent Lake vein quartz related to sulphide deposition (Table 3) reflects either the actual range in formation temperatures at constant pressure, or fluctuating fluid pressures during the episodic crack-seal cycles of the veins.

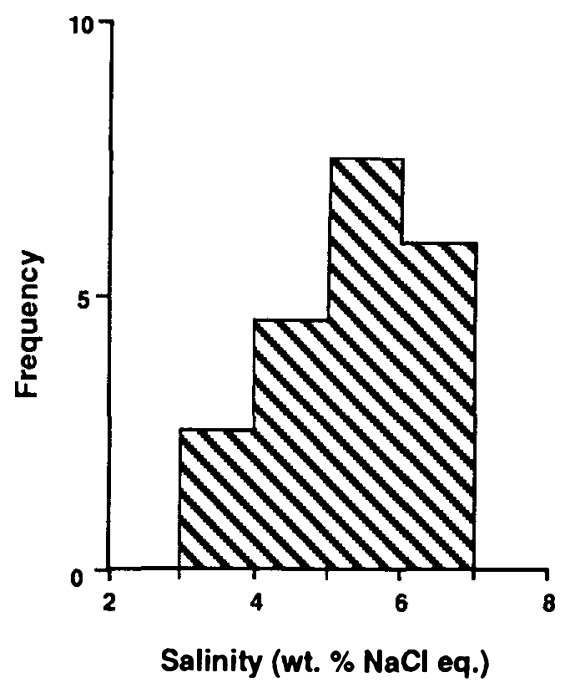

Fig. 7. The narrow range of melting temperatures of primary fluid inclusions from vein quartz (Table 3 ) indicate relatively constant salinities of the Crescent Lake hydrothermal fluids in the range of 3-7 wt. \% $\mathrm{NaCl}$ equivalent. No daughter crystals or gases such as $\mathrm{CO}_{2}$ were found.

$\mathrm{Fe}, \mathrm{Mn}$, and $\mathrm{Mg}$ in all chlorite analysis; natural sphalerite for $\mathrm{Zn}$, $\mathrm{Fe}$, and $\mathrm{S}$ in the sphalerite anaylsis; and Co metal for $\mathrm{Co}$, natural chalcopyrite for $\mathrm{Cu}, \mathrm{Fe}$, and $\mathrm{S}$, and natural millerite for $\mathrm{Ni}$ in the carrollite analysis.

\section{Chlorite analyses}

Chlorites were analysed in order to differentiate between orebearing and indigenous chlorite in the host rock. Chlorite adjacent to the veins and in country rock $50 \mathrm{~m}$ away in an area of barren quartz-epidote-feldspar veins was sampled. Results are shown in Table 4. The structural formulae are calculated on the basis of 28 oxygens, and $\mathrm{Al}^{\mathrm{IV}}$ and $\mathrm{Al}^{\mathrm{VI}}$ values have been determined based on $8 \mathrm{Si}+\mathrm{Al}^{\mathrm{IV}}$ (Deer et al., 1962). The microprobe does not distinguish between divalent and trivalent iron, but typically $95 \%$ of iron in chlorite is ferrous (Cathelineau and Nieva, 1985).

Sulphide-associated chlorite at Crescent Lake has a higher $\mathrm{Fe} /$ $\mathrm{Fe}+\mathrm{Mg}$ ratio $(\sim 0.51)$ than chlorite associated with barren veins $(\sim 0.42)$ (Table 4). Several thin sections from mineralized quartz veins at Crescent Lake contain chlorite with a distinctive blue birefringence, characteristic of chlorites with high $\mathrm{Fe} / \mathrm{Fe}+\mathrm{Mg}$ ratios (Saggerson and Turner, 1982; Kranidiotis and MacLean, 1987). Similar Fe-rich chlorites occur in other $\mathrm{Cu}$ deposits in Robert's Arm volcanic rocks (Bachinski, 1976).

Chromium occurs in sulphide-associated chlorite but not in the barren zone (Table 4). Although Pilley's Island chlorite is interpreted as $\mathrm{Mg}$-rich (without analyses), they are $\mathrm{Cr}$-rich like Crescent Lake and also contain anomalous Ni and $\mathrm{Co}$ (Bowles, 1987). The presence of carrollite at Crescent Lake indicates that Cr-Co-Ni-bearing fluids were responsible for both deposits-a possible genetic link.

\section{Genetic significance of chlorite compositions}

For chlorites in the Si-Al-Mg-Fe system, Fe substitutes extensively for $\mathrm{Mg}$, providing a tool to differentiate between chlorites formed from $\mathrm{Mg}$-rich and $\mathrm{Fe}$-rich hydrothermal fluids. The $\mathrm{Fe} /$ $\mathrm{Fe}+\mathrm{Mg}$ ratio of a fluid may vary because of (1) the source of the fluid (i.e., $\mathrm{Mg}$-rich seawater or $\mathrm{Fe}$-rich metamorphic or juvenile water); (2) the history of reaction with the host rock [i.e., extensive reaction of $\mathrm{Mg}$-rich seawater with basalt produces an Fe-rich fluid (Seyfried and Bischoff, 1981)]; or (3) mixing of fluids of different compositions. Chlorites from the Crescent Lake deposit are relatively $\mathrm{Fe}$-rich, suggesting that the fluids are either juvenile or highly reacted seawater.

The presence of $\mathrm{Cr}$ is not uncommon in chlorites because $\mathrm{Cr}^{+3}$ may substitute for $\mathrm{Al}^{+3}$ (Foster, 1962). The $\mathrm{Cr}$ may have been leached either from an ultramafic body, or from magnetite during sulphidization reactions between the basaltic host rocks and sulphur-rich fluids to form pyrite.

\section{Chlorite geothermometer}

The method of Cathelineau and Nieva (1985), which correlates $\mathrm{Al}^{\mathrm{IV}}$ content of chlorite with independently calculated and measured temperatures, was applied to the Crescent Lake chlorites. Kranidiotis and MacLean's (1987) equation:

$\mathrm{T}^{\mathrm{P}} \mathrm{C}=106 \mathrm{Al}^{\mathrm{IV}}+18$

was used, with their correction for varying $\mathrm{Fe} / \mathrm{Fe}+\mathrm{Mg}$ ratios changed to the general relation:

$\mathrm{Al}^{\mathrm{Iv}}$ corrected $=\mathrm{Al}^{\mathrm{Iv}}$ sample $-0.7\{(\mathrm{Fe} / \mathrm{Fe}+\mathrm{Mg})-0.3\}$

Kranidiotis and MacLean (1987) recommend its use in lowpressure ( $<100 \mathrm{MPa})$ and non-metamorphosed environments only, conditions which appear applicable to the Crescent Lake 
Table 4. Microprobe analyses of chlorites from the Crescent Lake area.

Ore Zone

CRL 11
Barren Zone CRL 10
Wt. \% Oxides

$\begin{array}{lrrrr}\mathrm{SiO}_{2} & 27.24 & 26.69 & 29.13 & 30.14 \\ \mathrm{Al}_{2} \mathrm{O}_{3} & 17.96 & 19.19 & 16.32 & 14.23 \\ \mathrm{Cr}_{2} \mathrm{O}_{3} & 1.92 & 0.65 & 0.00 & 0.00 \\ \mathrm{FeO} & 25.85 & 25.61 & 22.68 & 22.17 \\ \mathrm{MnO} & 0.64 & 0.32 & 0.19 & 0.29 \\ \mathrm{MgO} & 14.41 & 13.70 & 17.45 & 17.87 \\ & & & & \\ \text { Total } & 88.02 & 86.17 & 85.78 & 84.70\end{array}$

Structural Formulae (28 oxygens)

\begin{tabular}{lllll}
$\mathrm{Si}$ & 5.77 & 5.74 & 6.17 & 6.45 \\
$\mathrm{Al}^{\text {iv }}$ & 2.23 & 2.26 & 1.83 & 1.55 \\
$\mathrm{Al}^{\text {i }}$ & 2.26 & 2.61 & 2.24 & 2.04 \\
$\mathrm{Cr}$ & 0.32 & 0.11 & 0.00 & 0.00 \\
$\mathrm{Fe}$ & 4.58 & 4.61 & 4.02 & 3.97 \\
$\mathrm{Mn}$ & 0.12 & 0.06 & 0.03 & 0.05 \\
$\mathrm{Mg}$ & 4.55 & 4.39 & 5.51 & 5.70 \\
$\mathrm{Fe} / \mathrm{Fe}+\mathrm{Mg}$ & 0.50 & 0.51 & 0.42 & 0.41 \\
\hline
\end{tabular}

deposit. Another condition assumed by Kranidiotis and MacLean (1987) is that the chlorites are Al-saturated for equation 1 to apply. On a Hey (1954) diagram, the ore-stage chlorites are more Al-rich than the barren chlorites and plot within the field used by Kranidiotis and MacLean (1987), but are Al-undersaturated, even though sericite is found in the alteration (Swinden, 1987). However, because the Los Azufres data (Cathelineau and Nieva, 1985) used to determine equation 1 are similarly Al-undersaturated, we will assume that equation 1 can be used to estimate formation temperatures of the Crescent Lake chlorites.

Average formation temperatures of $240^{\circ} \mathrm{C}\left(s=2^{\circ}\right)$ for sulphideassociated chlorites are obtained, comparing well with the fluid inclusion homogenization temperatures of $112-250^{\circ} \mathrm{C}$ in mineralized quartz veins. The hydrothermal chlorite temperature of $240^{\circ} \mathrm{C}$ is near the high end of the $T_{b}$ range and because it is pressure-independent, may provide a better estimate of the true trapping temperature: the wide range of $T_{b}$ 's obtained may only reflect fluctuations in crack-seal fluid pressures, as mentioned earlier.

A revised relationship between $\mathrm{Al}^{\mathrm{IV}}$ and temperature was obtained by Cathelineau (1988), using the combined field data from the Los Azufres geothermal and Salton Sea (McDowell and Elders, 1980). With the exception of two points, both data sets appeared compatible and gave the relation:

$\mathrm{T}^{\mathrm{C}} \mathrm{C}=321.98 \mathrm{Al}^{\mathrm{IV}}-61.92$
( $\mathrm{Al} \mathrm{I}^{\mathrm{v}}$ based on 14 oxygens) for a temperature of $300^{\circ} \mathrm{C}\left(\mathrm{s}=4^{\circ}\right)$ for the ore zone chlorites, significantly higher than the $240^{\circ} \mathrm{C}$ temperature calculated above. However, because the $\mathrm{Al}^{\mathrm{IV}}$ variation with $\mathrm{Fe} / \mathrm{Fe}+\mathrm{Mg}$ content (equation 2) is not considered in equation 3 , we assume that $240^{\circ} \mathrm{C}$ is closer to the real formation temperature of the Crescent Lake hydrothermal chlorites.

\section{Sulphide analysis}

Microprobe analysis of $\mathrm{Fe}$ in chalcopyrite-diseased sphalerite was carried out at the University of Toronto. Copper was analyzed simultaneously with iron and zinc in the sphalerite, and the amount of chalcopyrite-bound $\mathrm{Fe}(\mathrm{Cu} / \mathrm{Fe}=1$; Yund and Kullerud, 1966) subtracted to obtain the Fe content in sphalerite. Calculated values for Crescent Lake sphalerite range between 4.7 and 5.6 mole-\% FeS, outside the $<1$ mole-\% FeS range of Kuroko stockwork veins (Bryndzia et al., 1983) but within the range of associated $\mathrm{Cu}-\mathrm{Pb}-\mathrm{Zn}$ veins (Hattori and Sakai, 1979).

\section{SULPHUR ISOTOPES}

\section{Samples and methodology}

Thirteen sulphide separates, including 7 chalcopyrite, 1 diseased sphalerite, and 5 fractured pyrite, were obtained from 20 polished slabs for sulphur isotope measurements to determine geochemical conditions and possible sources of sulphur. The chalcopyrite and sphalerite separates were drilled and measured directly; gangue contamination in the 5 pyrite separates was removed by the nitric acid-bromine oxidation method (Thode $e t$ al., 1961) to form barium sulphate. Isotope analyses were measured on a VG mm602C mass spectrometer at the National Hydrological Research Institute by J. Nriagu.

\section{Sulphur isotope results}

Crescent Lake sulphides have positive $\left({ }^{34} \mathrm{~S}\right.$-enriched, or isotopically heavy) values compared to the Canon Diablo troilite standard (Table 5). The $\partial^{34} \mathrm{~S}$ ranges are narrow for each mineral: pyrite, 5.0-6.2 \%o; chalcopyrite, 2.2-3.4 $\%$; the single sphalerite value is $2.3 \%$, or $2.2 \%$ when corrected for chalcopyrite content. These values are much lighter than the minimum value of $11-12 \%$ expected in volcanogenic sulphides derived from $29 \%$ Early Ordovician seawater sulphate (Sangster, 1968; Claypool et al., 1980), but similar to the 2.5-7.6\% range from the Gull Pond copper-bearing stockwork, also in Robert's Arm volcanic rocks (Bachinski, 1978).

Fractionation beween sulphide minerals in isotopic equilibrium enriches ${ }^{34} \mathrm{~S}$ in the order: pyrite > sphalerite > chalcopyrite $>$ galena (Kyser, 1987). The pyrite and chalcopyrite values from Crescent Lake agree with this trend (Table 6). (Sphalerite is always contaminated with chalcopyrite, and galena is too fine grained to be separated.) Fractionation between pyrite and chalcopyrite from the same samples is constant $\left(\Delta_{p y \subset p} \approx 2.7\right)$, suggesting isotopic equilibrium even though they are of different paragenetic ages (Fig. 4). Pyrite-chalcopyrite pairs from 3 samples 
Table 5. Sulphur isotope analyses from Crescent Lake Mine.

\begin{tabular}{|c|c|c|}
\hline Sample & Mineral & $\partial^{34} \mathrm{~S}(\% / 00)$ \\
\hline CRL 6 & pyrite & 5.2 \\
\hline CRL 6 & pyrite & 5.5 \\
\hline CRL 11 & pyrite & 5.4 \\
\hline CRL 12 & pyrite & 5.0 \\
\hline CRL 15 & pyrite & 6.2 \\
\hline CRL 1 & chalcopyrite & 3.4 \\
\hline CRL 1 & chalcopyrite & 3.3 \\
\hline CRL 6 & chalcopyrite & 2.7 \\
\hline CRL 11 & chalcopyrite & 2.8 \\
\hline CRL 12 & chalcopyrite & 2.3 \\
\hline CRL 12 & chalcopyrite & 2.3 \\
\hline CRL 12 & chalcopyrite & 2.2 \\
\hline CRL 6 & sphalerite (cp) & 2.3 \\
\hline
\end{tabular}

yield consistent sulphur isotope temperatures of $133-140^{\circ} \mathrm{C}$ (table 10 in Ohmoto and Rye, 1979), within the range of homogenization temperatures from fluid inclusions. Isotopic temperatures from one pyrite-sphalerite pair and one chalcopyrite-sphalerite pair are anomalously low, suggesting either isotopic disequilibrium or an unrepresentative sphalerite value. No ${ }^{34} S$ values are available from Pilley's Island, but Gull Pond sulphides have a similar range (2.5-7.6\%) as Crescent Lake (Bachinski, 1978).

\section{Genetic significance of $\partial^{34} \mathrm{~S}$ values}

The $2^{34} \mathrm{~S}$ values of sulphides depend upon the physical and chemical conditions of the ore-forming fluid ( $\mathrm{T}, \mathrm{pH}, \mathrm{fO}_{2}, \mathrm{etc}$.), bulk sulphur isotope composition, and the amount of interchange between the fluid and country rock (water/rock ratio) (Ohmoto, 1986). If isotopic equilibrium exists between the sulphide minerals and thus with the ore-forming fluid, general inferences about sulphur source, formation temperatures, and geochemical environment can be made.

For coeval sulphides, isotopic equilibrium suggests an abundance of sulphur available in the fluid. In the case of Crescent Lake, even though the sulphides are not coeval, the conformity with the equilibrium fractionation trend, coupled with the narrow ranges, suggests a homogeneous sulphur supply of consistent composition throughout the ore-forming process. Any mixing of fluids was thoroughly completed by the time it reached the vein system.

\section{DISCUSSION OF CHARACTERISTICS AND GENESIS}

\section{Summary of deposit characteristics}

Our petrographic, geochemical, and isotopic data provide some constraints on the nature and origin of the Crescent Lake deposit. The mineralization comprises sheeted (crack-seal) quartz veins with chalcopyrite and pyrite, and lesser sphalerite and galena. Vein opening occurred in a tensional regime; there is no evidence of shearing or faulting associated with the vein formation and mineralization. Copper is the dominant mineral of economic interest, although zinc and silver are locally anomalous. Geochemical anomalies in $\mathrm{Pb}, \mathrm{As}, \mathrm{Sb}$, and $\mathrm{Au}$ also occur.

Minor hydrothermal chlorite and altered rock inclusions occur in the quartz veins, and a narrow halo of chlorite-pyrite alteration exists around the veins. The sulphide and oxide minerals were deposited with quartz in five paragenetic stages: pyrite; galenasphalerite; chalcopyrite; pyrite; and covellite-iron oxide.

Homogenization temperatures of ore-stage quartz are wideranging $\left(112-250^{\circ} \mathrm{C}\right)$ with peaks at $130-140^{\circ} \mathrm{C}$ and $200-220^{\circ} \mathrm{C}$. This bimodality may reflect pressure fluctuations during repeated vein opening, and the pressure-independent chlorite crystallization temperature of $240^{\circ} \mathrm{C}$ being closer to the true trapping temperature. No evidence of boiling is seen, requiring a minimum formation depth of $\sim 430 \mathrm{~m}$. No $\mathrm{CO}_{2}$ is present. Salinities range narrowly between 3.3 and $6.6 \% \mathrm{NaCl}$ equivalent.

Analyses of hydrothermal chlorite indicate an $\mathrm{Fe}$ - rather than $\mathrm{Mg}$-rich fluid. The $\partial^{34} \mathrm{~S}$ values of 2.2-6.2 \% are similar to both VMS and Archean lode gold deposits (Franklin et al., 1981; Roberts, 1988) but indicate that some sulphur was derived from the host volcanics. Isotopic disequilibrium between coeval mineral pairs but apparent equilibrium between non-coeval pyrite and chalcopyrite suggests a homogeneous sulphur source over the duration of the hydrothermal system rather than high sulphur activity.

\section{Genetic models}

The Crescent Lake deposit is clearly epigenetic with respect to its host rocks, a feature expected for both VMS stockwork zones and for later mineralization related to tectonism or intrusion. Although mesothermal gold veins are widespread in the Robert's Arm Group (Hudson and Swinden, 1989, 1990), a number of features argue against a mesothermal origin for the Crescent Lake deposit: (1) the lack of associated shearing and deformation; (2) dominant $\mathrm{Cu}-\mathrm{Pb}-\mathrm{Zn}-\mathrm{Ag}$ mineralogy with minor $\mathrm{Au}, \mathrm{As}$, and $\mathrm{Sb}$; (3) lack of carbonate minerals in the veins and alteration zones; and (4) lack of $\mathrm{CO}_{2}$ in fluid inclusions and salinities higher than the 0-3\% typical of mesothermal gold deposits.

The mineralization is more consistent with a volcanogenic origin as suggested by Dean (1977). The quartz and sulphide paragenesis of the Crescent Lake deposit is consistent with that found in the Kuroko stockworks (Pisutha-Amond and Ohmoto, 1983). The deposition of galena and sphalerite before chalcopyrite and the attendant 'chalcopyrite disease' is characteristic of Kuroko ores in general (Barton, 1978) and is commonly interpreted as more intense and hotter hydrothermal activity (Eldridge et al., 1983).

The chlorite alteration is characteristic of VMS alteration such as in the Pilley's Island stockwork (Tuach, 1984). Salinities of inclusion fluids are similar to those in the Kuroko stockworks (3.6-7\% NaCl equivalent; Pisutha-Amond and Ohmoto, 1983; Bryndzia et al., 1983). The sulphur isotopes and high-Fe chlorites are consistent with VMS deposits, although not diagnostic. 
Table 6. Geothermometry determinations from sulphur isotope pairs.

\begin{tabular}{lccccccccc}
\hline Sample & $\partial^{34} S_{\text {py }}$ & $\partial^{34} S_{\text {cp }}$ & $\partial^{34} S_{\text {sp }}$ & $\Delta$ py-cp & $T^{\circ} \mathrm{C}$ & $\Delta$ py-sp & $T^{\circ} \mathrm{C}$ & $\Delta$ cp-sp & $T^{\circ} \mathrm{C}$ \\
\hline CRL 1 & - & 3.4 & - & - & - & - & - & - & - \\
CRL 6 & 5.4 & 2.7 & 2.3 & 2.7 & 138 & 3.0 & 42 & 0.4 & na \\
CRL 11 & 5.4 & 2.8 & - & 2.6 & 140 & - & - & - & - \\
CRL 12 & 5.0 & 2.3 & - & 2.7 & 133 & - & - & - & - \\
CRL 15 & 6.2 & - & - & - & - & - & - & - & - \\
\hline
\end{tabular}

Our preferred interpretation is that the Crescent Lake deposit represents alteration and mineralization in a volcanogenic hydrothermal system, possibly related to the Pilley's Island system. In the absence of detailed geochemical data from Pilley's Island, we cannot further corroborate this connection. However, geologic and whole-rock geochemical evidence suggest that the Crescent Lake deposit occurs near the base of the same calcalkalic basalt and andesite sequence that culminates in the extrusion of a dacite dome and VMS formation in the Pilley's Island area.

\section{CONCLUSIONS}

The present study suggests that the Crescent Lake copper deposit is related to a volcanogenic hydrothermal system rather than a mesothermal auriferous hydrothermal system. The episodic fracture fillings of quartz and sulphides could represent the deeper portions of a Kuroko-type system such as Pilley's Island massive sulphides. Further documentation of the Pilley's Island isotope and mineral chemistry is needed to determine how closely Crescent Lake and Pilley's Island are related.

\section{ACKNOWLEDGEMENTS}

We thank Bob Drimmie, Don Helm, and Peter Fisher of the University of Waterloo for their assistance in sulphur isotopes, thin sections, and photography, respectively, and George Jenner of Memorial University of Newfoundland for geochemical analyses and interpretations. Claudio Cermignani of University of Toronto carried out the microprobe work. Special thanks is extended to Andrea Scott for her support and assistance to the first author. Funding for this project was provided by the $\mathrm{Geo}$ logical Survey of Canada under the Canada-Newfoundland Mineral Development Agreement, 1984-1989, and a Natural Sciences and Engineering Research Council of Canada grant URF0037724 to E.C. Jowett. H.S. Swinden publishes with the permission of the Assistant Deputy Minister, Geological Survey Branch, Newfoundland Department of Mines and Energy.

BACHINSKI, D.J. 1976. Metamorphism of cupriferous iron sulphide deposits, Notre Dame Bay, Newfoundland. Economic Geology, 71, pp. 443-452.

1978. Sulphur isotopic composition of thermally metamorphosed cupriferous iron sulphide ores associated with cordierite- anthophyllite rocks, Gull Pond, Newfoundland. Economic Geology, 73, pp. 64-72.

BARTON, P.B., Jr. 1978. Some ore textures involving sphalerite from the Furutobe mine, Akita Prefecture, Japan. Mining Geology, 28, pp. 293-300.

BARTON, P.B., Jr. and BETHKE, P.M. 1987. Chalcopyrite disease in sphalerite: pathology and epidemiology. American Mineralogist, 72. pp. $451-467$.

BOSTOCK, H.H. 1978. The Roberts Arm Group, Newfoundland: Geological notes on a middle or upper Ordovician island arc environment. Geological Survey of Canada, Paper 78-15, 21 p.

1988. Geology and petrochemistry of the Ordovician volcanoplutonic Robert's Arm Group, Notre Dame Bay, Newfoundland. Geological Survey of Canada, Bulletin 369, 84 p.

BOWLES, E.G. 1987. Wallrock alteration, West Mine-Pilleys Island, Newfoundland. Unpublished M.Sc. thesis, University of Waterloo, Waterloo, Ontario, $136 \mathrm{p}$.

BRYNDZIA, L.T., SCOTT, S.D., and FARR, J.E. 1983. Mineralogy, geochemistry, and mineral chemistry of siliceous ore and altered footwall rocks in the Uwamuki 2 and 4 deposits, Kosaka Mine, Hokuroko Districh, Japan. Economic Geology, Monograph 5, pp. 506-522.

CATHELINEAU, M. 1988. Cation site occupancy in chlorites and illites as a function of temperature. Clay Minerals, 23, pp. 471-485.

CATHELINEAU, M. and NIEVA, D. 1985. A chlorite solid solution geothermometer. The Los Azufres (Mexico) geothermal system. Contributions to Mineralogy and Petrology, 91, pp. 235-244.

CLAYPOOL, G.E., HOLSER, W.T., KAPLAN, I.R., SAKAI, H., and ZAK, I. 1980. The age curves of sulphur and oxygen isotopes in marine sulphate and their mutual interpretation. Chemical Geology. 28, pp. 199-260.

DEAN, P.L. 1977. A report on the geology and metallogeny of the Notre Dame Bay to accompany metallogenic maps $12 \mathrm{H} / 1,8,9$ and $2 \mathrm{E} /$ 3,4,5,6,7,9,10,11,12. Newfoundland Department of Mines and Energy, Mineral Development Division, Report 77-10, 17 p.

1978. The volcanic stratigraphy and metallogeny of Notre Dame Bay. Memorial University of Newfoundland, St. John's, Geology Report 7. 204 p.

DEER, W.A., HOWIE, R.A., and ZUSSMAN, J. 1962. Rock-Forming Minerals, Volume 3, Sheet Silicates. Longman's, London, pp. 131163.

ELDRIDGE, C.S., BARTON, P.B., Jr., and OHMOTO, H. 1983. Mineral textures and their bearing on formation of the Kuroko orebodies. Economic Geology, Monograph 5, pp. 241-281.

ESPENSHADE, G.H. 1937. Geology and mineral deposits of the Pilley's Island area. Newfoundland Department of Natural Resources, Bulletin 6,56 p.

FOSTER, M.D. 1962. Interpretation of the composition and a classifi- 
cation of the chlorites. United States Geological Survey, Professional Paper 414-a, pp. A1-A33.

FRANKLIN, J.M., SANGSTER, D.M., and LYDON, J.W. 1981. Volcanic associated massive sulphide deposits. Economic Geology, 75th Anniversary Volume, pp. 485-627.

HAAS, J.L., Jr. 1971. The effect of salinity on the maximum thermal gradient of a hydrothermal system at hydrostatic pressure. Economic Geology, 66, pp. 940-946.

HATTORI, K. and SAKAI, H. 1979. D/H ratios, origins, and evolution of the ore-forming fluids for the Neogene veins and Kuroko deposits of Japan. Economic Geology, 74, pp. 535-555.

HEY, M.H. 1954. A new review of the chlorites. Mineralogical Magazine, 30, pp. 277-292.

HOWSE, A.F. and McARTHUR, J.G. 1977. Preliminary report and proposal for crown properties. Newfoundland Department of Mines and Energy, Mineral Development Division. Unpublished internal report, pp. 55-63.

HUDSON, K.A. and SWINDEN, H.S. 1989. Geology and petrology of the Handcamp gold prospect, Robert's Arm Group, Newfoundland. Geological Survey of Canada, Paper 89-1B, pp. 93-105.

1990. The Lake Bond deposit: superimposed volcanogenic and synorogenic base and precious metal mineralization in the Robert's Arm Group, central Newfoundland. Atlantic Geology, 26, pp. 11-25.

JENNER, G.A., LONGERICH, H.P., JACKSON, S.E., and FRYER, B.J. 1990. ICP-MS - a powerful tool for high precision trace element analysis in earth sciences: evidence from analysis of selected USGS reference samples. Chemical Geology, 83, pp. 133-148.

KEAN, B.F., DEAN, P.L., and STRONG, D.F. 1981. Regional geology of the Central Volcanic Belt of New foundland. Geological Association of Canada, Special Paper 22, pp. 65-78.

KRANIDIOTIS, P. and MacLEAN, W.H. 1987. Systematics of chlorite alteration at the Phelps Dodge massive sulphide deposit, Matagami, Quebec. Economic Geology, 82, pp. 1898-1911.

KYSER,T.K. 1987.Equilibrium fractionation factors for stable isotopes. In Short Course in Stable Isotope Geochemistry of Low Temperature Fluids, Volume 13. Edited by T.K. Kyser. Mineralogical Association of Canada, pp. 1-84.

MacQUARRIE, R. 1976. Halls Bay South (Newfoundland) summary report. Unpublished report to Texasgulf Incorporated, pp. 98-119.

McDOWELL, S.D. and ELDERS, W.A. 1980. Authigenic layer silicate minerals in borehole Elmore 1, Salton Sea geothermal field, California, USA. Contributions to Mineralogy and Petrology, 74, pp. 293310.

MIYASHIRO, A. and SHIDO, F. 1975. Tholeiitic and calc-alkalic series in relation to the behaviour of titanium, vanadium, chromium, and nickel. American Journal of Science, 275, pp. 265-277.

OHMOTO, H. 1986. Stable isotope geochemistry of ore deposits. In Stable Isotopes in High Temperature Processes, Reviews in Mineralogy, Volume 16. Edited by J.W. Valley, H.P. Taylor, Jr., and J.R. O'Neil. Mineralogical Society of America, Washington, D.C., pp. 491-559.

OHMOTO, H. and RYE, R.O. 1979. Isotopes of sulphur and carbon. In Geochemistry of Hydrothermal Ore Deposits. Edited by H.L. Bames. John Wiley and Sons, New York, pp. 509-567.

PISUTHA-ARNOND, V. and OHMOTO, H. 1983. Thermal history and chemical isotopic compositions of the ore-forming fluids responsible for the Kuroko massive sulphide deposits in the Hokuroku District of Japan. Economic Geology, Monograph 5, pp. 523-558.

POTTER, R.W., Jr., CLYNNE, M.A., and BROWN, D.L. 1978. Freezing point depressions of aqueous sodium chloride solutions. Economic Geology, 73, pp. 284-285.
RAMDOHR, P. 1969. The Ore Minerals And Their Intergrowths. Pergamon Press, Oxford, pp. 686-691.

RAMSAY, J.G. 1980. The crack-seal mechanism of rock deformation. Nature, 284, pp. 135-139.

ROBERTS, R.G. 1988. Archean lode gold deposits. In Ore Deposit Models. Edited by R.G. Roberts and P.A. Sheahan. Geological Association of Canada, St. John's, pp. 2-20.

ROEDDER, E. 1984. Fluid Inclusions. Mineralogical Society of America, Reviews in Mineralogy, 12, 664 p.

SAGGERSON, E.P. and TURNER, L.M. 1982. General comments on the identification of chlorites in thin section. Mineralogical Magazine, 46, pp. 469-473.

SANGSTER, D.F. 1968. Relative sulphur isotope abundances of ancient seas and stratabound sulphide deposits. Geological Association of Canada Proceedings, 19, pp. 79-89.

SEYFRIED, E.E. and BISCHOFF, J.L. 1981. Experimental seawaterbasalt interaction at $300^{\circ} \mathrm{C}$ and 500 bars: chemical exchange, secondary mineral formation and implications for transport of heavy metals. Geochemica et Cosmochimica Acta, 45, pp. 135-147.

SIBSON, R.H. 1981. Fluid flow accompanying faulting: field evidence and models. In Earthquake Prediction: An Intemational Review. Edited by D.W. Simpson and P.G. Richards. American Geophysical Union, pp. 593-603.

STRONG, D.F. 1977. Volcanic regimes of the Newfoundland Appalachians. Geological Association of Canada, Special Paper 16, pp. 61 90.

SUN, S.S. 1980. Lead isotope study of young volcanic rocks from midocean ridges, ocean islands, and island arcs. Philosophical Transactions, Royal Society of London, A297, pp. 409-445.

SWINDEN, H.S. 1987. Geology and mineral occurrences in the central and northern parts of the Roberts Arm Group, central Newfoundland. In Current Research, Part A, Geological Survey of Canada, Paper 871A, pp. 381-390.

SWINDEN, H.S. and SACKS, P.E. 1986. Stratigraphy and economic geology of the southem part of the Roberts Arm Group, central Newfoundland. In Current Research, Geological Survey of Canada, Paper 86-1A, pp. 213-220.

SWINDEN, H.S., TUACH, J., KEAN, B.F., and DEAN, P.L. 1988. Road log for the Badger-Beothuck Trail excursion. In The Volcanogenic Sulphide Districts of Central Newfoundland. Edited by H.S. Swinden and B.F. Kean. Geological Association of Canada, pp. 131141.

THODE, H.G., MONSTER, J., and DUNFORD, H.B. 1961. Sulphur isotope geochemistry. Geochimica et Cosmochimica Acta, 25, pp. 159-174.

THURLOW, J.G., SWANSON, E.A., and STRONG, D.F. 1975. Geology and lithogeochemistry of the Buchans polymetallic sulphide deposits, Newfoundland. Economic Geology, 70, pp. 130-144.

TUACH, J. 1984. Geology and volcanogenic sulphide mineralization in the Robert's Arm Group on Pilley's Island, central Newfoundland. In Mineral Deposits of Newfoundland - A 1984 Perspective. Edited by H.S. Swinden. Newfoundland Department of Mines and Energy, Mineral Development Division, Report 84-3, pp. 117-130.

TUACH, J., DEAN, P.L., SWINDEN, H.S., O'DRISCOLL, C.F., KEAN, B.F., and EVANS, D.T.W. 1988. Gold mineralization in Newfoundland: a 1988 review. Current Research, Newfoundland Department of Mines and Energy, Mineral Development Division, Report 88-1.

YUND, R. and KULLERUND, G. 1966. Thermal stability of assemblages in the Cu-Fe-S system. Journal of Petrology, 7, pp. 454-488. 